KEIO/KYOTO JOINT

GLOBAL CENTER OF EXCELLENCE PROGRAM

Raising Market Quality-Integrated Design of "Market Infrastructure"

KEIO/KYOTO GLOBAL COE DISCUSSION PAPER SERIES

DP2012-020

\title{
Skew productivity distributions and agglomeration: Evidence from plant-level data
}

\author{
Toshihiro Okubo* \\ Eiichi Tomiura**
}

\begin{abstract}
This paper empirically examines how the shapes of plant productivity distributions vary across regions based on Japan's manufacturing census. We focus on the skewness to examine the asymmetry by estimating the gamma distribution at the plant level. By linking the estimated shape parameters with economic geography variables, we find that the productivity distribution tends to be significantly left-skewed, especially in cores, regions with diversified industrial compositions, regions with weak market potential, and in agglomerated industries. These findings suggest that agglomeration economies are likely to accommodate heterogeneous plants with wide ranges of productivities.

*Toshihiro Okubo

Faculty of Economics, Keio University

**Eiichi Tomiura

Department of Economics, Yokohama National University
\end{abstract}

KEIO/KYOTO J OINT GLOBAL COE PROGRAM

Raising Market Quality-Integrated Design of "Market Infrastructure"

Graduate School of Economics and Graduate School of Business and Commerce,

Keio University

2-15-45 Mita, Minato-ku, Tokyo 108-8345, Japan

Institute of Economic Research,

Kyoto University

Yoshida-honmachi, Sakyo-ku, Kyoto 606-8501, Japan 


\title{
Skew productivity distributions and agglomeration: \\ Evidence from plant-level data
}

Revised: November 6, 2012; Original submission: November 25, 2011

\begin{abstract}
This paper empirically examines how the shapes of plant productivity distributions vary across regions based on Japan's manufacturing census. We focus on the skewness to examine the asymmetry by estimating the gamma distribution at the plant level. By linking the estimated shape parameters with economic geography variables, we find that the productivity distribution tends to be significantly left-skewed, especially in cores, regions with diversified industrial compositions, regions with weak market potential, and in agglomerated industries. These findings suggest that agglomeration economies are likely to accommodate heterogeneous plants with wide ranges of productivities.
\end{abstract}

Keywords: agglomeration; productivity; skewness; heterogeneity; plant-level data JEL Classifications: L11; R12

\section{Introduction}

Productivity considerably differs across industries, plants, and regions. While previous literature has already established agglomeration premium in average productivity, little is known about distributional information and its linkage with economic geography. This paper empirically investigates the shapes of regional productivity distributions, especially the skewness to examine the asymmetry of productivity distributions across plants, based on plant-level data derived from Japan's manufacturing census, and discusses how they are related with agglomeration. The asymmetry, not captured by the mean or the dispersion of distributions, is an important concept, as it has deep implications for such various policy issues as competition policy, urban policy, regional economic policy, and small- and medium-sized enterprises. The welfare or distributional impacts of policy measures, such as subsidizing low-productivity local 
firms, should critically differ across regions with different skewness of productivity distributions even if the average productivity is initially at the same level in all regions. For example, subsidies for the survival of small-sized firms is more effective in the regions with more left-skewed distributions, since many low-productivity firms, which are often small in size, are more likely to coexist with the high-productivity dominant firm in those regions.

This paper covers all plants with no less than four employees in all manufacturing industries across all regions in Japan over six consecutive waves of censuses. We investigate how the shape of gamma distribution (skewness) is related with the following economic geography variables: Ellison-Glaser index of industrial agglomeration, Harris index of market potential, Krugman index of regional specialization, and regional entropy index. Industry, region, and year-specific effects are controlled for in the fixed effect model of panel data.

To preview our main results, the productivity distributions of plants tend to significantly deviate from the log-normal distribution. By linking the estimated shape parameters with economic geography variables, the current paper finds that the plant productivity distribution tends to be less left-skewed (closer to the log-normal distribution) in regions with stronger market potential, but more left-skewed (unproductive plants distributed along longer left-tail of productivity distribution) in agglomerated industries or regions with diverse industrial structures. These findings suggest critical roles of externality in shaping the distribution of productivity.

Although this paper is not intended to test specific hypothesis directly derived from structural New Economic Geography (NEG) models, it is informative to refer to a theoretical model in line with our empirical findings. Okubo, Picard and Thisse (2010) show that high-productivity firms and low-productivity firms can co-exist within agglomerated regions. ${ }^{1}$ Firms located in larger regions need to face tougher competition but benefit from a better

1 Okubo, Picard and Thisse (2010) consider only two levels (high or low) of productivity levels without assuming any firm productivity distributions. 
proximity to larger pools of customers. In the real world, many small-sized suppliers with relatively low productivity may operate in close proximity to a large, productive final assembler by providing inputs tailored to complicated assembler's requirements, probably facilitated by face-to-face contacts and local knowledge spillovers. Larger local demand may also allow heterogeneous firms to survive in the same region by supporting wider varieties of product differentiation. These are consistent with our finding of left-skewed productivity distribution in agglomerated regions/industries.

The rest of this paper is organized as follows. Section 2 reviews related previous studies and explains the motivations of our research. Section 3 describes our manufacturing census data. Section 4 summarizes plant-level distributional information, and relates the estimated shape parameters to economic geography. Section 5 adds concluding comments.

\section{Previous literature and our motivations}

This section briefly overviews related literature and explains the main motivations of our study. Previous empirical research on productivity and geography has been already abundant. On the average productivity, accumulated studies as surveyed in Rosenthal and Strange (2004) and Melo et al. (2009) have established that productivity on average is high in agglomerated areas. On the dispersion, Syverson (2004a) argues that larger local demand leads to a productivity distribution truncated from below due to intensified competition, and finds empirical evidence consistent with this prediction in the case of the ready-made concrete industry. ${ }^{2}$

While previous studies have examined the first or second moment (i.e. mean or dispersion) of productivity distributions, we focus on the third moment: skewness to examine how asymmetric the productivity distribution is (i.e. whether the distribution has a longer tail

\footnotetext{
2 Syverson (2004b) compares 443 U.S. manufacturing industries and finds lower dispersion in industries with higher substitutability, which is proxied by value/weight ratio or shipped distance.
} 
over lower or higher productivity ranges) and compare the asymmetry across regions. The asymmetry is important in its own right when we discuss real-world issues. For example, even if the mean and the dispersion of productivity distributions are the same between two regions, relatively unproductive firms are more likely to coexist with highly productive firms in the region with more left-skewed distributions. This should result in different policy prescriptions in competition policy or urban policy. We need to be careful in discussing economic policies for regions with different distributions.

In estimating the shape parameter of distribution, we choose the generalized gamma distribution, following Cabral and Mata (2003), and Barrios et al. (2005). Although many empirical studies have reported that firm size tends to be distributed log-normal following Gibrat's law, some researchers have paid attention to skewness at least since Ijiri and Simon (1977) for example, and these two papers apply the gamma distribution to Portuguese and Irish firm-level data. ${ }^{3}$ The gamma distribution is also used in the theoretical model of firm growth by Luttmer (2005) in explaining the deviation from log-normality.

We must note that the current NEG models (e.g. Baldwin and Okubo, 2006) start their analysis by assuming that the productivity of firms follows Pareto distribution, as their main focus is on the inter-firm heterogeneity rather than its distributional shape. Therefore, this paper is not a test of specific theoretical hypothesis directly derived from existing structural NEG models. This paper is intended to provide empirical evidence on the non-negligible asymmetry of distributions. Our descriptive findings will hopefully inspire and enrich future economic geography models by bringing attentions to the real-world asymmetry in analyzing productivity distributions.

3 Cabral and Mata (2003) also report that the distribution becomes closer to log-normal as firms get older, but Angelini and Generale (2008) find no significant impact of financial constraints on this evolution of distributions in OECD data. 
To be more precise, this paper estimates gamma parameters but also relates them with economic geography variables. While a main focus of NEG models is not the investigation of productivity distributions, it is still informative to discuss how our estimated skewness is related with standard variables in NEG models for deriving economic implications. In the previous studies, for example, Masili (2005) relates industrial characteristics (e.g. R\&D intensity) with cumulative distribution function of firm size to examine market concentration. Soo (2005) relates regional and other factors with Pareto exponent of city size distributions to discuss urban agglomeration. This paper regresses estimated skewness on such economic geography variables as market potential, industrial agglomeration and regional specialization, and discusses their implications.

Before explaining our empirical results, a brief reference to an important recent paper should be in order. While previous studies have shown that stronger selection due to intensified competition in larger regions truncates the productivity distribution from below/left, Combes et al. (2010) distinguish this effect from agglomeration by noting that agglomeration shifts the distribution to the right. ${ }^{4}$ While their econometric method is novel in nesting selection with agglomeration, the skewness cannot be captured by left-truncation or right-shift of distributions. $^{5}$

\section{Data description}

This section is devoted to the explanations of our micro-data derived from Japan's Census of Manufacturers. ${ }^{6}$ This census covers virtually all plants across all manufacturing industries.

\footnotetext{
${ }^{4}$ Combes et al. (2010) also consider the case that agglomeration dilates the distribution and apply their method to French establishment-level data.

${ }^{5}$ Furthermore, as reported in Section 4.1, the selection appears not to be critical in our comparison of Japanese prefectures, while Combes et al. (2010) analyze French cities.

6 Henderson (2003) studied Marshallian externality based on U.S. Census of Manufacturers.
} 
Although the annual survey covers plants above the given size threshold, small-sized plants are included only in the "census years" (years with a $0,3,5$, or 8 as its last digit). As the principal purpose of this paper is the investigation of productivity distributions over the entire population of plants, we concentrate on census years to avoid truncations due to the sampling of plants. While plants of any size, including those with only one employee, are covered by the census, plant-level data are maintained only for the plants with no less than four employees in the original micro-data files of the central government even for the most recent census. As a result, our sample excludes plants with less than four employees. Since these extremely small-sized plants produce negligible volumes of output, their omission is unlikely to affect our conclusion on economic geography.

Our sample consists of the following six census years: 1978, 1980, 1983, 1985, 1988, and 1990, since the plant-level data before the mid-1970s are no longer available, even from the original government data files. By using these six consecutive waves of manufacturing censuses, we can investigate the productivity distributions over Japan's history from the oil crises (1973) to the bubble economy (several years prior to 1992).

We decide to focus on these earlier years from the following reasons. From the 1990s onward, plant location decisions by Japanese firms have become increasingly global due to expanded production overseas (in particular toward Asia) by Japanese multinationals, accelerated by the unprecedented exchange rate appreciation. No information on offshore production, however, is available in the domestic manufacturing census. Furthermore, the spread of information and communication technology, most notably the Internet, has changes corporate organization and blurred firm boundary by active offshore outsourcing. The Japanese economy in our sample period before the 1990s did not experience substantial foreign direct investment, offshoring or international outsourcing, and thus enables us to examine plant 
locations within Japan. In parallel, this period corresponds to the transition from the bi-polar urban system driven by Tokyo and Osaka to the mono-polar urban system leading to mega-concentration in Metropolitan Tokyo, as suggested by Fujita and Tabuchi (1997). Therefore, the period of the 1970s and 80s, which is our data sample, involves many interesting questions on spatial patterns of plant location and is an appropriate period over which to investigate relationships among location, productivity and market competition without taking into account overseas production and hollowing-out.

The manufacturing census contains basic information on plant-characteristics, such as output (shipment), and employment (number of regular workers). As no plant identifier tracing micro-data over time is available for this period, our data set is unfortunately in the format of repeated cross-sections. Since the main target of this paper is the comparison of productivity between core and periphery regions, not on the entry-exit dynamics of plants, this data limitation is unlikely to affect our principal conclusions.

Productivity is measured by per-worker value-added. We note that as some previous studies discussed, the productivity measured by per-worker value-added is not crucially different from other productivity measures. ${ }^{7}$ As a robustness check, we also calculate Total Factor Productivity (TFP) based on a limited sample of 1986-1990, for which longitudinal plant identifier are available. In calculating TFP, we apply the method by Olley and Pakes (1996) to the longitudinal data of plants with available data on capital.

The territory of Japan is divided into 47 prefectures, each of which roughly corresponds to a NUTS2 region. To identify the agglomeration effect, we focus on the three prefectures with the biggest population: Tokyo, Osaka, and Aichi. These prefectures are obvious economic centers and the core regions of Japan, as they account for around 32 percent of industrial output,

7 The results are unlikely to be qualitatively affected by the choice of productivity measures. See Bernard and Jones (1996), for example. 
26 percent of manufacturing output, 32 percent of GDP, and 22 percent of the population of Japan in 2005. To check the robustness of our focus on these three prefectures, we also examine the Greater Tokyo Area and the Greater Osaka Area by including neighboring prefectures. ${ }^{8}$ This paper defines these regions (Tokyo, Osaka, Aichi, Greater Tokyo, and Greater Osaka) as the core region (Core) and the others as the periphery region. To alleviate the arbitrariness of this definition of core, we will also consider various measures of agglomeration, localization, or concentration in our regressions. Basic statistics are summarized in Table 1.

\section{Empirical results}

\subsection{Productivity distributions}

This section summarizes distributional patterns of productivity at the plant level. We present the contrast between core and peripheral regions, as well as within-industry distributions. Distributional assumptions are also discussed.

\subsubsection{Core-periphery differentials}

Figure 1 presents the distributions of plant productivity in Kernel density estimates at 1990. The distributional patterns clearly differ between core and peripheral regions. The distribution in peripheral regions is relatively close to the log-normal distribution, but that in core regions is more left-skewed. We test whether the productivity distribution is significantly different between core and peripheral regions, based on the non-parametric Kolmogorov-Smirnov (KS) test. As the results from KS tests are statistically significant with zero associated p-values, we confirm that the productivity distribution in the core is

\footnotetext{
${ }^{8}$ We define Greater Tokyo Area (nation capital area, or shuto-ken in Japanese) as Tokyo and neighboring prefectures: Kanagawa, Chiba and Saitama. Greater Osaka Area (Kyoto-Osaka-Kobe Area, or Keihanshin in Japanese) is defined as Osaka and the neighboring Kyoto and Hyogo prefectures.
} 
significantly different from that in the periphery. ${ }^{9}$ As a robustness check, Figure 1 confirms that similar patterns remain even if we measure productivity in terms of TFP.

Although these density graphs demonstrate a non-negligible core-periphery gap, we need to check the possibility that these cross-regional variations in productivity distributions may be merely due to differences in industrial compositions (due to higher share of high-productivity industries located in core regions). ${ }^{10}$ For this purpose, we present Kernel density estimates for major industries in Figure 2. These industry-specific results confirm that our previous finding is not entirely driven by differences in industrial compositions. Productivity remains distributed more left-skewed in core regions than that in periphery even within each industry. The contrast is the sharpest in electric machinery, while the distributional shape and the core-periphery gap vary depending on the industry. ${ }^{11}$

\subsubsection{Agglomeration and plant heterogeneity}

Although we have reported a significant core-periphery differential in the mean productivity, the heterogeneity across plants should be addressed in analyzing the gap between core and periphery. As surveyed in Section 2, intensive competition allows only productive plants to survive in agglomerated regions. This selectivity of plants implies the left-truncation of productivity distributions. The observed core-periphery gap in average productivity might be affected by this possible truncation. Consequently, we use propensity score matching (PSM) to handle this issue.

The results from our PSM have confirmed that the average productivity remains significantly different between core and periphery even within a limited sample of matched

9 The test statistics are available upon request.

10 Holmes and Stevens (2002) show the strong connection between firm size and industry concentration.

11 Comparable graphs for all other two-digit industries are shown in the discussion paper version. 
plants based on PSM. ${ }^{12}$ As additional evidence in line with this PSM result, visual inspections of Figures 1 and 2 also suggest that the truncation appears not to be serious in our sample of Japanese prefectures with relatively large differentials in wages and in factor endowments. ${ }^{13}$ During our sample period of 1978-90, the competition in Japan has obviously become intensified due to development of infrastructure such as highways or to trade liberalization, but the distributional shapes remain stable over years. ${ }^{14}$ Based on these observations, this paper focuses on the distributional shapes instead of truncation in what follows.

\subsubsection{Distributional assumptions}

This sub-section discusses distributional assumptions for examining the plant productivity. We first test whether the productivity distribution is log-normal. ${ }^{15}$ The skewness and kurtosis statistics significantly reject the log normality in all prefectures. This result leads us to estimate under alternative distributional assumption. This paper chooses the gamma distribution following Cabral and Mata (2003) and Barrios et al. (2005) to investigate the higher moment (the skewness) of productivity distribution. ${ }^{16}$ The gamma distribution is also examined by Luttmer (2007) in theoretically explaining firm growth. Our focus on the shape parameter differentiates us from previous work neglecting higher moments of productivity distributions.

We estimate the extended generalized gamma distribution with a probability density

\footnotetext{
12 We use employment size, labor-output ratio, material-output ratio and sector dummies in the first-stage regression for PSM, as the data on capital are unavailable for many small-sized plants. The average productivity in core is still higher than in periphery by $4.00 \%$ after PSM, though the differential becomes smaller than $4.65 \%$ based on the simple mean comparison without plant matching. The gap is statistically significant at any conventional significance level. The detailed PSM results are available upon request.

13 Frequency histograms before Kernel smoothing are available upon request. We compare prefectures in Japan, while Combes et al. (2010) compare cities in France.

${ }_{14}$ Graphs for different years are shown in the discussion paper version and available upon request.

15 Appendix Figure A1 visually shows the comparisons with log-normal distribution.

16 Both Cabral and Mata (2003) and Barrios et al. (2005) estimate the distribution of firm size, not of plant productivity.
} 
function defined as follows:

$$
\begin{aligned}
& \frac{|\kappa|}{\Gamma\left(\kappa^{-2}\right)}\left(\kappa^{-2}\right)^{-2} \exp \left(\kappa^{-2}(\kappa q-\exp (\kappa q))\right) \quad \kappa \neq 0 \\
& \frac{1}{\sqrt{2 \pi}} \exp \left(-1 / 2 q^{2}\right) \quad \kappa=0
\end{aligned}
$$

where $q \equiv(\ln \operatorname{prod}-\mu) / \sigma$ is a function of plant productivity prod, with its mean $\mu$ and standard deviation $\sigma$. The shape parameter of the gamma distribution is expressed by $\kappa . \Gamma$ denotes the gamma function. When $\kappa=1$, the distribution coincides with Weibull. When $\kappa$ goes to zero, it becomes log-normal, as specified in (2). When $\kappa$ is positive in (1), the distribution is left-skewed. ${ }^{17}$ As positive $\kappa$ gets larger as shown by an example in Figure 3, the distribution is more left-skewed (with longer tail toward lower productivity ranges).

The productivity distribution in each prefecture is estimated at the plant level for each year. ${ }^{18}$ All of the $\kappa$ 's are significantly positive and less than one. This implies that productivity distributions are left-skewed in all regions. Statistical tests also confirm that the productivity distribution is neither long-normal or Weibull. As the estimated values of $\kappa$ substantially vary across prefectures, we will investigate the links with geographical factors.

As we observe wide cross-industry variations in productivity distributions, we next disaggregate industries. Though it is ideal to separately estimate each industry in each prefecture, maximum-likelihood estimations of the gamma distribution often fail to converge in reasonable numbers of iterations. As a result, we estimate productivity distribution of each industry for each year in core and peripheral regions separately. ${ }^{19}$ The next section investigates the linkage between the each industry's estimated shape parameter and industrial characteristics.

\footnotetext{
17 We note that the skewness statistics is negative (the density is called negatively-skewed) when $\mathrm{K}$ of the gamma distribution is positive.

18 The estimated gamma parameters for all 47 prefectures are reported in the discussion paper version and available upon request.

19 The estimated $\kappa$ for each industry is omitted but available upon request.
} 


\subsection{Regression estimations}

This section relates the estimated shape parameters of generalized gamma distribution with regional and sectoral variables to provide economic interpretations. Region- or industry-specific effects and year effects are controlled for in panel regressions.

\subsubsection{Region-year panel regressions}

To investigate how economic geography affects plant productivity distributions, we estimate the following equation. The dependent variable of the regression is the shape parameter $\kappa$ for each prefecture in each year, which is derived from the generalized gamma distribution in the previous section. As region-year panel regressions, we estimate ${ }^{20}$

$$
\kappa_{r t}=\alpha_{0}+\alpha_{1} \mu_{r t}+\alpha_{2} \sigma_{r t}+\beta_{1} M P_{r t}+\beta_{2} E N T R P Y_{r t}+\beta_{3} K S_{r t}+\gamma_{t}+\delta_{r}+u_{r t} .
$$

The region (prefecture) and the year are denoted by $r$ and $t$, respectively. All 47 prefectures at six census years are covered in estimating (3). On the right-hand side of the regressions, economic geography variables are included as explained below. As this specification controls for the first and second moments of the gamma distribution, the estimated relation with geography variables is interpreted as that given $\mu$ and $\sigma$. As the skewness has no systematic relation with the first or second moment in the gamma distribution, the endogeneity problem due to the inclusion of $\mu$ and $\sigma$ is unlikely to be serious in this regression. ${ }^{21}$ Year effect $\gamma$ and prefecture effect $\delta$ are captured in the fixed-effects model applied to our panel data. Error term is represented by $u$.

20 Soo (2005) estimates a similar regression with the country's Pareto exponent of city size distribution as the dependent variable.

${ }^{21}$ In our sample, the correlations between the moments actually turn out to be low. Related with this issue, Huber and Pfaffermayr (2010) investigate the second and third moments of firm size distribution separately and demonstrate that Gibrat's law "may be compatible with both an increase and a decrease in the skewness" (p.649). 
Economic geography variables defined below are included on the right-hand side of the panel regression (3). First, we introduce the market potential MP as in Harris (1954) by

$$
M P_{r t} \equiv \sum_{m=1}^{47} \frac{G D P_{m t}}{D_{r m}}
$$

where $D_{r m}$ is geographical distance between capitals of prefectures $r$ and $m .^{22}$ Regions with strong market potential are likely to attract plants and to have intense competition.

As a measure of urbanization or diversity, we use the entropy index ENTRPY defined by

$$
E N T R P Y_{r t} \equiv-\sum_{j} s_{j r t} \log _{2} s_{j r t}
$$

where $s_{j r t}$ denotes the employment share of industry $j$ in prefecture $r$ at year $t$. Higher entropy means that the region has more diversified composition of industries and hence plants located in these regions receive benefits from externality due to cross-industry knowledge fertilization or input-output linkages. Urbanized regions with diverse industrial compositions are more likely to accommodate plants with wide ranges of productivity levels, as diverse and differentiated plants can coexist in rich urban environment.

To check the robustness, we add the following three variables related with agglomeration: PLANTS (the number of manufacturing plants), DID (the share of the population in Densely Inhabited Districts), ${ }^{23}$ and/or INFRA (per-capita public capital stock for industrial use) ${ }^{24}$ in each region. PLANTS is a measure of external economies of scale in manufacturing. DID is intended to measure congestion costs. INFRA is included to capture government investment for

22 When $m=r$, the internal distance is calculated by $\frac{2}{3} \sqrt{\frac{\text { Area }}{\pi}}$ where "Area" denotes area of the prefecture r. (See Combes and Overman, 2004)

23 Densely Inhabited District is defined by the district of which population density is more than 4,000 people per square kilometer and population in adjacent area is more than 5,000. The data is taken from the Population Census.

24 The prefecture data for GDP, population and infrastructure are taken from Fukao and Yue (2000)'s data set. 
supporting rural areas. As a further robustness check, we also use other alternative measures of agglomeration, for which the estimation results are shown in Appendix. ${ }^{25}$

To control for cross-regional variations in industrial specialization, we include the Krugman index, which is defined as

$$
K S_{r t} \equiv \sum_{j}\left|s_{j r t}-s_{j t}\right|
$$

where $s_{j t}$ denotes the share of industry $j$ in Japan's total manufacturing employment at year $t$.

This index takes the value of zero when the region's industrial structure is the same as the national average. While urbanization indices consider the region as a whole, Krugman's index focuses on how the region deviates from the average in its industrial composition

Table 2 reports the fixed-effect estimation results from region-year panel regressions. Several findings are worth noting. First, the shape parameter $\kappa$ in regions with strong market potentials tends to be significantly low, implying less left-skewed productivity distribution, given the mean and dispersion of the gamma distribution for $0<\kappa<1$. In other words, relatively few unproductive plants along the left-tail of distributions survive in these regions. This indicates that competition intensified by strong market potential leads the distribution to be close to the log-normal distribution. This finding is in line with Cabral and Mata (2003) in that they discover that distribution becomes closer to log-normal as firms get older through competition.

Second, the productivity distribution tends to be significantly more left-skewed (higher $\kappa$ ) in regions with higher entropy. As the entropy index is designed to measure the extent of diversity or urbanization of the region, this finding indicates that plants with wide productivity ranges (especially low-productivity ranges) coexist along long left-tail of productivity

25 Regressions in Appendix Table A1 use the estimated result from Otsuka and Yamano (2008) of the contribution of TFP to growth over 1980-2002 for each prefecture. In their regressions, population density and market access index are also included. 
distributions in regions with diversified industrial structures. The number of plants in the region is also significantly positively related, in line with our result on entropy index. Additional regressions with alternative measures of agglomeration in Appendix Table A1 confirm the significantly positive relation with $\kappa$. Infra and DID are, on the other hand, negative, suggesting that plants with low productivity levels cannot survive in rural areas requiring heavy public investment supports or in densely populated congested areas. These results combined indicate that urban diversity or agglomeration alleviates the intensity of local competition.

On the other hand, higher Krugman index of industrial specialization appears to be weakly related with higher $\kappa$, suggesting that plants with wider ranges of productivities survive in regions specializing in industries different from the national average. Specialization into different industrial composition appears to result in more agglomeration in specialized industries and less direct competition against other regions.

Finally, when we look at the relations with the moments of gamma distribution, regions with higher $\kappa$ tend to have significantly higher mean $\mu$. The standard deviation $\sigma$ also appears to be positively related though with weaker statistical significance. This result indicates that regions with higher average productivity are likely to have more left-skewed productivity distributions. As established results have already confirmed higher average productivity in core or agglomeration regions, this shows that productivity distributions in core/agglomerated regions tend to have many relatively unproductive plants along long left-tails, given productivity dispersion.

\subsubsection{Industry-year panel regressions}

While the previous regression (3) is designed to investigate variations across regions/years, we next estimate the following industry-year panel regression. 


$$
\begin{aligned}
\kappa_{c j t}= & \lambda_{0}+\lambda_{1} \mu_{c j t}+\lambda_{2} \sigma_{c j t}+\theta_{1} E G_{j t}+\theta_{2} \text { Trade }_{j t}+\theta_{3} \text { Trans }_{j t}+\theta_{4} \text { Info }_{j t} \\
& +\eta \cdot \text { CORE }_{c}+\pi_{j}+\rho_{t}+v_{j t}
\end{aligned}
$$

The industry is denoted by $j$. The dependent variable in this specification is the shape parameter of each industry/year, estimated separately for core and peripheral regions. ${ }^{26}$ In the regression (7), we distinguish core and periphery as the regional identifier $c$ with the dummy for core regions $(C O R E=1$ for $c=$ core, 0 for $c=$ periphery). Both industry effect $\pi$ and year effect $\rho$ are captured in the fixed-effect model. As in (3), the mean and standard deviation of the gamma distribution are also controlled for. Error term is expressed by $v$. Industry-specific variables included in the regression are as follows.

First, $E G$ is the Ellison-Glaeser index of industrial agglomeration (Ellison and Glaeser, 1997) defined by

$$
E G_{j t}=\frac{\frac{\sum_{r}\left(s_{j r t}-s_{r t}\right)^{2}}{\left(1-\sum_{r} s_{r t}^{2}\right)}-H_{j t}}{\left(1-H_{j t}\right)}
$$

where $s_{j r t}$ denotes the employment share of industry $j$ in region $r$, and $s_{r t}$ is the share of region $r$ in terms of total manufacturing employment at year $t$, as before. $H_{j}$ is the Herfindahl index of plant size distribution in industry $j$. EG index measures how the industry is geographically concentrated with adjustment of intra-industry plant concentration. For a robustness check, we also use an alternative measure of industrial localization proposed as K-density by Duranton and Overman (2005), which is not based on administrative units (prefectures in our construction of EG index) but on geographic distance between plants, and thus robust with respect to aggregation levels of administrative units. We will report the alternative estimation results with

${ }^{26}$ Marsili (2005) estimates a similar sectoral regression with Pareto CDF as the dependent variable. 
K-density in Appendix. ${ }^{27}$

Second, to investigate the impact of exposure to international trade, we include Trade, which is measured by the share of trade (export plus import) in total output in each sector, derived from Input-Output Tables. ${ }^{28}$ This variable captures the intensity of foreign competition.

Finally, we add industry-specific transport cost variable Trans defined by the expenditures on transportations divided by output, both derived from Input-Output Tables. ${ }^{29}$ Transport costs affect total costs and thus influence the survival of plants. For a similar purpose, we also include the share of expenditures on information and communication Info as an additional control.

Fixed-effect panel regression results with disaggregated industries are reported in Table 3. We must note several interesting results. First, the significantly positive CORE in all columns of this table demonstrates that productivity distributions in core regions tend to be significantly more left-skewed than those in peripheral regions. This result confirms our prior visual inspection of Kernel density estimates in Figures 1 and 2, and is also consistent with our findings from cross-regional regressions, though core-periphery industry-year panel data cannot distinguish each prefecture. ${ }^{30}$ We also detect positive coefficients on industry's $\mu$ and $\sigma$ as in cross-regional regressions. While the average productivity is actually higher in cores than in peripheral regions (more productive plants in cores), this regression result is on the comparison of distributional shapes after controlling for differences in $\mu$ and $\sigma$.

Second, the Ellison-Glaeser index is estimated to be positive in many specifications. ${ }^{31}$ This implies that agglomerated industries tend to have productivity distributions with longer

27 Regressions in Appendix Table A2 use the K-density of Japanese industries estimated by Nakajima et al. (2012). See Appendix-2 for detail.

28 Trade share at 1990 is included into the regressions after interacted with year dummies, as we cannot trace sectoral trade data back to the 1970 s on a consistent basis.

29 All Input-Output Tables data are derived from Japan Industrial Productivity database. Both variables are included into the regressions after interacted with year dummies.

30 Okubo and Tomiura (2012) find that policies for relocating plants out of cores affect the shapes of productivity distributions in Japan.

31 As this index barely varies over time, we include it after interacted with year dummies. 
left-tails over lower productivity ranges. Insignificant relationships in later years might be affected by such various factors as expanding transactions with non-manufacturing (service) industries. Regression results with an alternative measure of industrial localization (K-density) reported in Appendix Table A2 confirm this finding from EG index.

Third, the share of foreign trade is significantly negatively related with $\kappa$ in all years when we control not only for the industry's transport costs but also for the extent of information and communication activities. ${ }^{32}$ Industries more exposed to international competition tend to have productivity distribution less left-skewed, indicating that intensified competition across borders results in fewer low-productivity plants along the left-tail of distribution. This industrial result echoes our previous regional finding on market potential, and is also in line with Giovanni et al. (2011), as they find that the size distribution is more right-skewed among exporting firms than in non-exporting firms based on French firm-level data. ${ }^{33}$ We also find a similarly negative relation with transport costs, indicating that unproductive plants cannot profitably operate under heavy transport cost burden. On the other hand, a positive coefficient on Info suggests that plants with relatively low production efficiency can survive in information-intensive industries, but this effect becomes blurred in later years possibly by the introduction of inter-firm computer-networks or Internet.

In sum, our regression results, cross-regional and cross-sectoral regressions combined, show that the productivity distribution tends to be significantly more left-skewed (i.e. more unproductive plants) in cores, in regions with weaker market potentials, industries with lower shares of foreign trade, regions with diverse industrial compositions, and in agglomerated regions/industries. These suggest that, while intensified competition tends to make distributions

32 Even if we replace EG index by K-density in Appendix Table A2, the sign of the coefficient on foreign trade remains mostly negative though statistically insignificant.

33 As a related result, Marsili (2005) finds that increased mobility of firms across sizes makes distributions less skewed toward small firms by estimating the impacts of technology variables. 
closer to log-normal, agglomeration economies appear to facilitate heterogeneous plants with wider ranges of productivity levels to coexist within the same region.

\section{Concluding remarks}

This paper empirically studies the shapes of productivity distributions based on plant-level data derived from Japan's manufacturing census. There are, however, some aspects not captured by the simple economic geography models. First, the distribution of plant productivity is left-skewed and is far from a log-normal distribution. Second, peripheral regions, especially regions with good access to neighboring markets, have tougher competition and productivity distributions are less left-skewed. Finally and much more importantly, a countervailing force works in core regions, which have been neglected in previous empirical work concentrating on means and standard deviations of productivity distributions. While the severe competition makes productivity distributions closer to log-normal distributions, the urban externality accommodates plants with wider ranges of productivity to survive within the same market.

The relation between productivity and agglomeration is thus more nuanced than that simply captured by the intensified competition. The plant-level findings reported in this paper are descriptive and by no means reject any theoretical models but have potentially important policy implications. Even if the mean and dispersion of productivity are the same in two regions, subsidizing R\&D investment for inducing the targeted firm to be the dominant leader is unlikely to be effective in the region with more left-skewed distribution where many unproductive firms survive. Cross-regional comparisons of productivity skewness are thus informative for policy discussions. As the impact of agglomeration on plant distribution is a critical concern for many producers and policy makers, comparable micro-data studies, preferably in longitudinal forms, in other countries will be useful in the future. 


\section{Reference}

Angelini, P., and Generale, A. (2008) "On the evolution of firm size distributions," American Economic Review, 98(1), 426-38.

Baldwin, R., and Okubo, T. (2006) "Heterogeneous firms, agglomeration and economic geography: spatial selection and sorting," Journal of Economic Geography 6, 323-346.

Barrios, S., Görg, H., Strobl, E. (2005) "The evolution of the firm size distribution and nationality of ownership," Economics Bulletin 12, 1-11.

Bernard, A., and Jones, C. (1996) "Comparing apples to oranges: productivity convergence and measurement across industries and countries," American Economic Review 86, 1216-1238.

Cabral, L., and Mata, J. (2003) "On the evolution of the firm size distribution: facts and theory," American Economic Review 93, 1075-1090.

Combes, P.-Ph., Duranton, G., Gobillon, L., Puga, D., and Roux, S. (2010) "The productivity advantages of large cities: Distinguishing agglomeration from firm selection," CEPR Discussion Paper.

Combes, P., and Overman, H. (2004) "The spatial distribution of economic activities in the European Union,” In: Henderson, J., and Thisse, J. (Eds), Handbook of Regional and Urban Economics, Vol.4, Elsevier, 2845-2909.

Duranton, G., and Overman, H. (2005) "Testing for localization using micro-geographic data," Review of Economic Studies 72, 1077-1106.

Ellison, G., and Glaeser, E. (1997) "Geographic concentration in U.S. manufacturing industries: A dartboard approach," Journal of Political Economy 105, 889-927.

Fujita, M., and Tabuchi, T. (1997) "Regional growth in postwar Japan," Regional Science and 
Urban Economics 27, 643-670.

Fukao, K and Yue, X. (2000) "Sengo Nihon-kokunai ni okeru Keizaishusoku to Seisanyouso Tounyu-Solow seicho moderu ha tekiyou dekiru ka (Economic convergence and production input in post-war Japan-An application of Solow economic growth model)," Keizai Kenkyu 52 (2).

Giovanni, J., Levchenko, A., and Rancière, R. (2011) "Power laws in firm size and openness to trade: Measurement and implications," Journal of International Economics 85, 42-52.

Harris, C. (1954) "The market as a factor in the localization of industry in the United States," Annals of American Geographers 64, 315-348.

Henderson, V. (2003) “Marshall's scale economies," Journal of Urban Economics 53, 1-28.

Holmes,T., and Stevens, J. (2002) "Geographic concentration and establishment scale," Review of Economics and Statistics, 84(4), 682-690.

Huber, P., and Pfaffermayr, M. (2010) "Testing for conditional convergence in variance and skewness: The firm size distribution revisited," Oxford Bulletin of Economics and Statistics 72(5), 648-668.

Ijiri, Y., and Simon, H. (1977) Skew Distributions and the Sizes of Business Firms, North Holland, Amsterdam.

Luttmer, E. (2007) "Selection, growth, and the size distribution of firms," Quarterly Journal of Economics 122, 1103-1144.

Marsili, O. (2005) "Technology and the size distribution of firms: Evidence from Dutch manufacturing," Review of Industrial Organization 27, 303-328.

Melo, P., Graham, D., and Noland, R. (2009) "A meta-analysis of estimates of urban agglomeration economies," Regional Science and Urban Economics 39, 332-342.

Nakajima, K., Umeno-Saito, Y., and Uesugi, I. (2012) "Measuring economic localization: 
Evidence from Japanese firm-level data," Journal of the Japanese and International Economies 26(2), 201-220.

Okubo, T., Picard, P.M., and Thisse, J-F. (2010) “The spatial selection of heterogeneous firms," Journal of International Economics 82(2), 230-237.

Okubo, T., and Tomiura, E. (2012) "Industrial relocation policy, productivity, and heterogeneous plants: Evidence from Japan,” Regional Science and Urban Economics 42, 230-239.

Olley, S., and Pakes, A. (1996) "The dynamics of productivity in the telecommunications equipment industry,” Econometrica 64, 1263-1297.

Otsuka, A., and Yamano, N. (2008) "Industrial agglomeration effects on regional economic growth: A case of Japanese regions," REAL Discussion Paper 08-T-2, University of Illinois.

Rosenthal, S., and Strange, W. (2004) "Evidence on the nature and sources of agglomeration economies," Chapter 49, in J. Henderson and J. Thisse (Eds) Handbook of Urban and Regional Economics vol.4, Elsevier, Amsterdam, 2119-2171.

Soo, K.T. (2005) “Zipf's law for cities: a cross-country investigation," Regional Science and Urban Economics 35, 239-263.

Syverson, C. (2004a) "Market structure and productivity: a concrete example," Journal of Political Economy 112, 1181-1222.

Syverson, C. (2004b) "Product substitutability and productivity dispersion," Review of Economics and Statistics 86, 534-550.

\section{Appendix Descriptions of variables for robustness checks}

1. Alternative variables for cross-regional regressions

To check the robustness of our results reported in the main text on the cross-regional 
regression (3), the regressions reported in Appendix Table A1 use alternative variables described below. For the estimates for Japanese prefectures, we employ the results by Otsuka and Yamano (2008). They estimate the standard trans-log production function with capital and labor for Japanese prefectures during 1980-2002, and regard TFP as a measure of agglomeration. Then, they decompose TFP into the following four parts: (1) the population density as a measure of urbanization ("urbanization"), (2) the total industrial production as a measure of localization ("localization"), (3) the market potential ("ma"), and (4) technological progress ("tech"). We use their estimated regression coefficients on these four variables for each prefecture as alternative measures of agglomeration in Appendix Table A1. As these estimates do not vary over years, we include them into our panel regressions after interacting with year dummies.

\section{Alternative measure of industrial localization for cross-industry regressions}

As a robustness check for the cross-industry regression (7), the regressions reported in Appendix Table A2 use an alternative measure of industrial localization. This measure is originally proposed as K-density by Duranton and Overman (2005) as an improvement over EG index. The localization index ("Loc") for Japanese industries which we use in Appendix Table A2 regressions is the estimates by Nakajima et al. (2012). They define localization based on a comparison with simulated counterfactual location distributions where all firms in the industry randomly choose their locations, and calculate the share of industries localized within 60 kilometers in the total number of four-digit industries for each two-digit industry. As their estimates are obtained from cross-section data, we include them into our panel regressions after interacting with year dummies. 
Figure 1: Productivity Distribution in Kernel Density (1990)

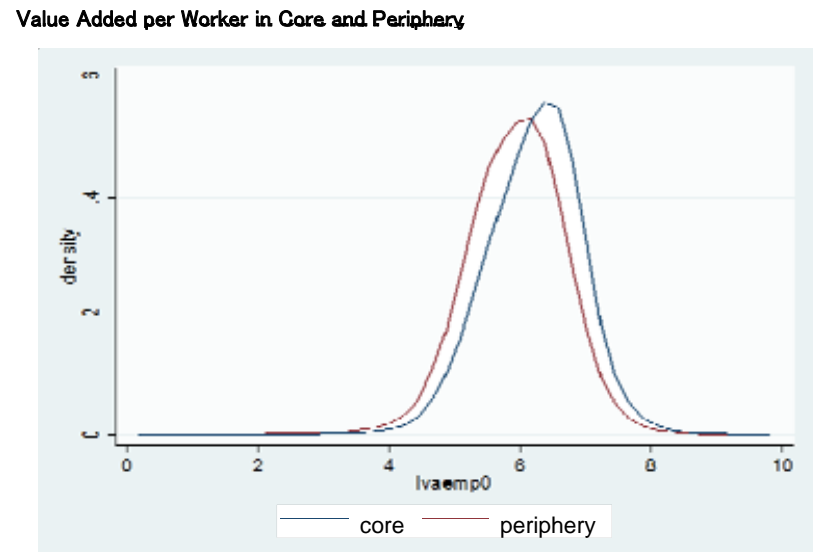

TFP in Core and Periphery

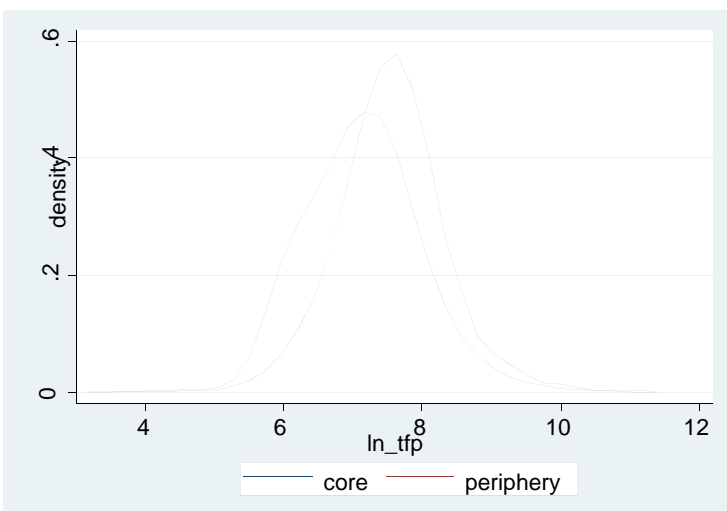

Figure 2: Kernel Density in Representative Sectors
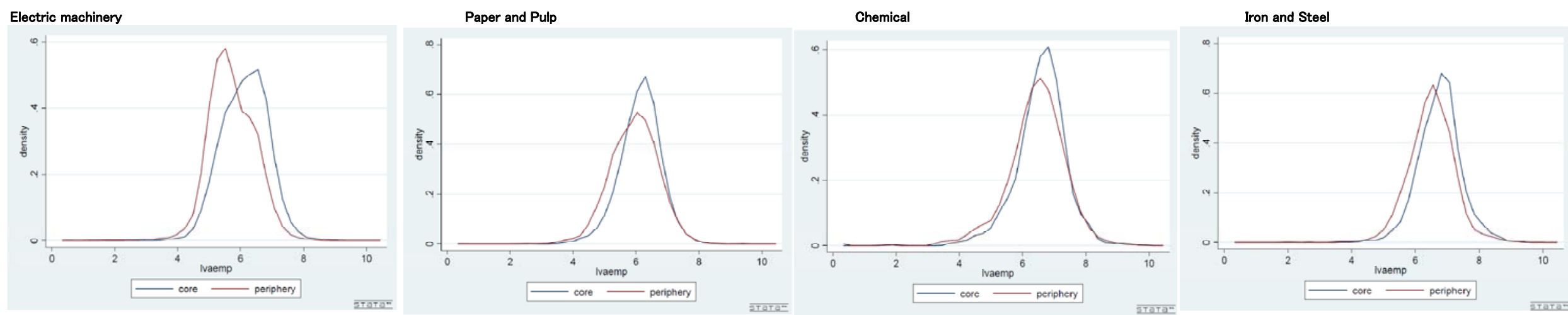


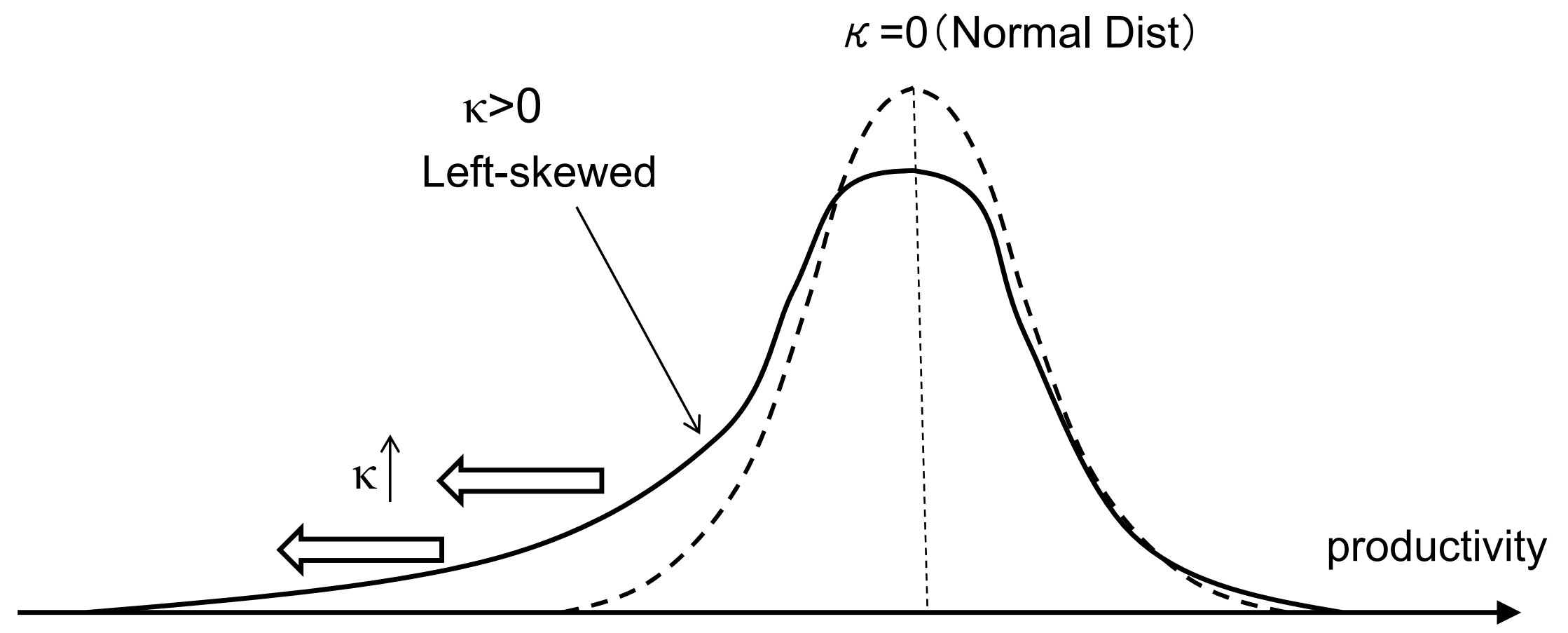

Figure 3: Gamma distribution and shape parameters ( $\mathrm{K}$ ) 


\section{Table 1: Basic Statistic}

Firm productivity (in logarithm)

\begin{tabular}{|c|c|c|c|c|c|c|}
\hline & 1978 & 1980 & 1983 & 1985 & 1988 & 1990 \\
\hline Obs & 348683 & 346333 & 355323 & 339814 & 332982 & 324687 \\
\hline & .466605 & 5.617749 & 5.712944 & 5.79242 & 5.902257 & 6.025851 \\
\hline & & 0.831771 & 0.829244 & 0.848545 & .832791 & \\
\hline & 09 & 691843 & 0.687645 & 028 & 541 & 0.769 \\
\hline & .30789 & -1.46736 & -1.46885 & -1.64182 & -1.59998 & -1.8487 \\
\hline & .96468 & 11.97741 & 12.03113 & 12.98473 & 13.01716 & \\
\hline \multicolumn{7}{|l|}{ percentail } \\
\hline $1 \%$ & 3.386809 & 62 & 3.55 & 3.55 & 3.772761 & 3.713572 \\
\hline $5 \%$ & 4.265025 & 4.3 & 4.49 & 348 & 4.688521 & 4.774913 \\
\hline $10 \%$ & 4.56 & & 4.7 & & 4.976 & 5.081 \\
\hline 25 & 5.01728 & 5.16 & 5.25 & 5.331 & 5.4375 & 5.55511 \\
\hline $50 \%$ & 5.509388 & 5.664695 & 5.766131 & 5.849325 & 5.959071 & 6.0898 \\
\hline 75 & 5.966916 & 6.126869 & 6.222472 & 6.316391 & 6.425949 & 6.57068 \\
\hline $90 \%$ & 6.367157 & 6.531461 & 6.620586 & 6.709914 & 6.809388 & 6.9675 \\
\hline $95 \%$ & 6.622838 & 6.790097 & 6.878326 & 6.958528 & 7.054782 & 7.210966 \\
\hline $99 \%$ & 7.200612 & 7.388603 & 7.473702 & 7.538894 & 7.617444 & 7.7679 \\
\hline
\end{tabular}

Regression Variables (regional regressions)

\begin{tabular}{lrrrrr} 
Variables & \multicolumn{2}{c}{ Mean } & \multicolumn{1}{c}{ Std.Dev } & \multicolumn{2}{c}{ Min } \\
\hline$\kappa$ & 282 & 0.6915 & 0.096453 & 0.392 & 0.994 \\
$\sigma$ & 282 & 3.289117 & 0.370678 & 0.292 & 4.246 \\
$\mu$ & 282 & 4.698151 & 0.41275 & 3.687618 & 8.208245 \\
MP & 282 & 14.0643 & 0.632308 & 12.31976 & 15.91758 \\
KS & 282 & 0.529467 & 0.15348 & 0.242133 & 1.046072 \\
DID & 282 & 0.433502 & 0.180862 & 0.209756 & 0.969981 \\
PLANTS & 282 & 8.750307 & 0.824496 & 7.131699 & 10.90658 \\
Infra & 282 & 14.01443 & 0.660407 & 12.65949 & 15.94146 \\
ENTRPY & 282 & 2.205287 & 1.478299 & 0.430444 & 7.275736 \\
localizatiol & 282 & 1.697255 & 0.649951 & 0.412 & 3.379 \\
urbanzatio & 282 & 0.202064 & 0.066909 & 0.018 & 0.31 \\
Technolog & 282 & 0.645426 & 0.042284 & 0.562 & 0.719 \\
MA & 282 & 0.006894 & 0.015135 & -0.022 & 0.042 \\
\hline
\end{tabular}

\begin{tabular}{|c|c|c|c|c|c|}
\hline \multicolumn{6}{|c|}{ Regression Variables (sectoral regressions) } \\
\hline Variables Obs & & Mean & Std.Dev & Min & Max \\
\hline$\kappa$ & 231 & -0.88984 & 2.381025 & -9.21713 & 0.602173 \\
\hline$\sigma$ & 231 & 1.460943 & 0.547726 & 0.224835 & 2.75363 \\
\hline$\mu$ & 231 & 1.39522 & 2718 & -0.00119 & 2.89256 \\
\hline$E G$ & 252 & 0.019355 & & -0.00535 & 0.108262 \\
\hline Trac & 228 & & & 858 & 0.520787 \\
\hline Trans & 228 & 0.045564 & 0.020163 & 0.020695 & 0.093609 \\
\hline Info & 228 & 0.013903 & 0.005936 & 0.004175 & 0.02611 \\
\hline Loc & 228 & 0.592267 & 0.249815 & 0.055556 & \\
\hline
\end{tabular}


Table 2: Regional Regressions

\begin{tabular}{|c|c|c|c|c|c|c|c|c|c|c|c|c|}
\hline & 1 & 2 & 3 & 4 & 5 & 6 & 7 & 8 & $3 \quad 9$ & 10 & 11 & 12 \\
\hline $\mathrm{mu}$ & $\begin{array}{l}0.075 \\
(5.30) * * *\end{array}$ & $\begin{array}{l}0.076949 \\
(5.52) * * *\end{array}$ & $\begin{array}{l}0.073 \\
(5.15) * * *\end{array}$ & $\begin{array}{l}0.076044 \\
(5.39) * * *\end{array}$ & $\begin{array}{l}0.075 \\
(5.30) * * *\end{array}$ & $\begin{array}{l}0.056 \\
(3.89) * * *\end{array}$ & $\begin{array}{l}0.042 \\
(3.11) * * *\end{array}$ & $\begin{array}{l}0.058 \\
(4.03) * * *\end{array}$ & $\begin{array}{l}0.069 \\
(4.88) * * *\end{array}$ & $\begin{array}{l}0.041 \\
(3.06) * * *\end{array}$ & $\begin{array}{l}0.058 \\
(4.05) * * *\end{array}$ & $\begin{array}{l}0.075 \\
(5.32) * * *\end{array}$ \\
\hline sigma & $\begin{array}{l}0.037 \\
(2.28) * * *\end{array}$ & $\begin{array}{l}0.035006 \\
(2.18) * *\end{array}$ & $\begin{array}{l}0.038 \\
(2.33) * * *\end{array}$ & $\begin{array}{l}0.035567 \\
(2.21) * *\end{array}$ & $\begin{array}{l}0.037 \\
(2.27) * * *\end{array}$ & $\begin{array}{l}0 \\
(-0.02)\end{array}$ & $\begin{array}{l}-0.011 \\
(-0.8)\end{array}$ & $\begin{array}{l}0.006 \\
(0.39)\end{array}$ & $\begin{array}{l}0.032 \\
(1.97) *\end{array}$ & $\begin{array}{l}-0.016 \\
(1.15)\end{array}$ & $\begin{array}{l}0.001 \\
(0.08)\end{array}$ & $\begin{array}{l}0.034 \\
(2.10) * *\end{array}$ \\
\hline MP & $\begin{array}{l}-0.113 \\
(5.63) * * *\end{array}$ & $\begin{array}{l}-0.12699 \\
(-6.17) * * *\end{array}$ & $\begin{array}{l}-0.128 \\
(4.76) * * *\end{array}$ & $\begin{array}{l}-0.13511 \\
(-5.04) * * *\end{array}$ & $\begin{array}{l}-0.091 \\
(-1.23)\end{array}$ & & & & & & & \\
\hline ENTRPY & $\begin{array}{l}0.085 \\
(3.77) * * *\end{array}$ & $\begin{array}{l}0.087326 \\
(3.90) * * *\end{array}$ & $\begin{array}{l}0.089 \\
(3.86) * * *\end{array}$ & $\begin{array}{l}0.089574 \\
(3.91) * * *\end{array}$ & $\begin{array}{l}0.084 \\
(3.69) * * *\end{array}$ & $\begin{array}{l}0.048 \\
(2.13) * *\end{array}$ & & & & $\begin{array}{l}0.047 \\
(2.06) * *\end{array}$ & $\begin{array}{l}0.05 \\
(2.25) * *\end{array}$ & $\begin{array}{l}0.08 \\
(3.61) * * *\end{array}$ \\
\hline PLANTS & & $\begin{array}{l}0.247876 \\
(2.60) * * *\end{array}$ & & $\begin{array}{l}0.241282 \\
(2.50) * *\end{array}$ & & & & & & & & \\
\hline DID & & & $\begin{array}{c}-0.319 \\
(-0.83)\end{array}$ & $\begin{array}{l}0.181478 \\
(-0.47)\end{array}$ & & $\begin{array}{l}-0.89 \\
(-2.97) * * *\end{array}$ & & $\begin{array}{l}-0.846 \\
(-2.82) * * *\end{array}$ & & & $\begin{array}{l}-0.884 \\
(-2.97) * * *\end{array}$ & \\
\hline Infra & & & & & $\begin{array}{l}-0.019 \\
(-0.32)\end{array}$ & & & & $\begin{array}{l}-0.072 \\
(-4.51) * * *\end{array}$ & & & $\begin{array}{l}-0.089 \\
(-5.45) * * *\end{array}$ \\
\hline KS & & & & & & & $\begin{array}{l}0.11 \\
(1.72) *\end{array}$ & $\begin{array}{l}0.108 \\
(1.71) *\end{array}$ & $\begin{array}{l}0.097 \\
(1.58)\end{array}$ & $\begin{array}{l}0.118 \\
(1.85) *\end{array}$ & $\begin{array}{l}0.116 \\
(1.86) *\end{array}$ & $\begin{array}{l}0.108 \\
(1.80) *\end{array}$ \\
\hline Constant & $\begin{array}{l}1.626 \\
(7.42) * * *\end{array}$ & $\begin{array}{l}-0.36072 \\
(-0.45)\end{array}$ & $\begin{array}{l}1.693 \\
(7.26) * * *\end{array}$ & $\begin{array}{l}-0.27006 \\
(-0.33)\end{array}$ & $\begin{array}{l}1.579 \\
(5.95) * * *\end{array}$ & $\begin{array}{l}0.708 \\
(6.27) * * *\end{array}$ & $\begin{array}{l}0.474 \\
(5.77) * * *\end{array}$ & $\begin{array}{l}0.708 \\
(6.11) * * *\end{array}$ & $\begin{array}{l}1.228 \\
(6.65) * * *\end{array}$ & $\begin{array}{l}0.387 \\
(4.22) * * *\end{array}$ & $\begin{array}{l}0.625 \\
(5.18) * * *\end{array}$ & $\begin{array}{l}1.248 \\
(6.93) * * *\end{array}$ \\
\hline Observatic & 282 & 282 & 282 & 282 & 282 & 282 & 282 & 282 & 282 & 282 & 282 & 282 \\
\hline Number of & 47 & 47 & 47 & 47 & 47 & 47 & 47 & 47 & 47 & 47 & 47 & 47 \\
\hline R-squared & 0.17 & 0.19 & 0.17 & 0.19 & 0.17 & 0.09 & 0.05 & 0.08 & 0.13 & 0.07 & 0.1 & 0.17 \\
\hline
\end{tabular}

$\mathrm{t}$-statistics in parentheses

* significant at $10 \%$ level, ** significant at $5 \%$ level; *** significant at $1 \%$ level 
Table 3: Sectoral Regressions

\begin{tabular}{|c|c|c|c|c|c|c|c|c|c|}
\hline & 1 & 2 & 3 & 4 & 5 & 6 & 7 & 8 & 9 \\
\hline $\mathrm{mu}$ & $\begin{array}{l}0.9 \\
(8.15) * * *\end{array}$ & $\begin{array}{l}0.842 \\
(7.63) * * *\end{array}$ & $\begin{array}{l}0.65 \\
(5.69) * * *\end{array}$ & $\begin{array}{l}0.858 \\
(7.14) * * *\end{array}$ & $\begin{array}{l}0.798 \\
(6.65) * * *\end{array}$ & $\begin{array}{l}0.644 \\
(5.80) * * *\end{array}$ & $\begin{array}{l}0.836 \\
(7.85) * * *\end{array}$ & $\begin{array}{l}0.846 \\
(7.04) * * *\end{array}$ & $\begin{array}{l}0.797 \\
(6.56) * * *\end{array}$ \\
\hline sigma & $\begin{array}{l}3.063 \\
(18.63) * * *\end{array}$ & $\begin{array}{l}3.131 \\
*(19.17) * * *\end{array}$ & $\begin{array}{l}3.339 \\
(19.36) * * *\end{array}$ & $\begin{aligned} & 3.223 \\
= & (18.36) * * *\end{aligned}$ & $\begin{array}{l}3.256 \\
(18.67) * * *\end{array}$ & $\begin{array}{l}3.328 \\
*(19.86) * * *\end{array}$ & $\begin{aligned} & 3.119 \\
= & (19.80) * * *\end{aligned}$ & $\begin{array}{l}3.238 \\
*(18.40) * * *\end{array}$ & $\begin{array}{l}3.267 \\
(18.63) * * *\end{array}$ \\
\hline core & $\begin{array}{l}0.663 \\
(5.99) * * *\end{array}$ & $\begin{array}{l}0.648 \\
(5.95) * * *\end{array}$ & & $\begin{array}{l}0.669 \\
(6.12) * * *\end{array}$ & $\begin{array}{l}0.646 \\
(6.06) * * *\end{array}$ & & $\begin{array}{l}0.645 \\
(6.15) * * *\end{array}$ & $\begin{array}{l}0.668 \\
(6.16) * * *\end{array}$ & $\begin{array}{l}0.648 \\
(6.09) * * *\end{array}$ \\
\hline$E G$ & & $\begin{array}{l}9.089 \\
(2.87) * * *\end{array}$ & $\begin{array}{l}10.001 \\
(2.92) * * *\end{array}$ & $\begin{array}{l}3.526 \\
(1.05)\end{array}$ & $\begin{array}{l}0.737 \\
(0.22)\end{array}$ & & & & \\
\hline EG1 & & & & & & $\begin{array}{l}21.851 \\
(4.02) * * *\end{array}$ & $\begin{array}{l}20.258 \\
(4.06) * * *\end{array}$ & $\begin{array}{l}0.265 \\
(0.04)\end{array}$ & $\begin{array}{l}-3.159 \\
(-0.4)\end{array}$ \\
\hline EG2 & & & & & & $\begin{array}{l}15.352 \\
(3.22) * * *\end{array}$ & $\begin{array}{l}14.366 \\
(3.28) * * *\end{array}$ & $\begin{array}{l}0.423 \\
(0.07)\end{array}$ & $\begin{array}{l}-3.231 \\
(-0.46)\end{array}$ \\
\hline EG3 & & & & & & $\begin{array}{l}20.488 \\
(3.23) * * *\end{array}$ & $\begin{array}{l}20.362 \\
(3.50) * * *\end{array}$ & $\begin{array}{l}1.09 \\
(0.13)\end{array}$ & $\begin{array}{l}-3.802 \\
(-0.41)\end{array}$ \\
\hline EG4 & & & & & & $\begin{array}{l}1.563 \\
(0.26)\end{array}$ & $\begin{array}{l}1.026 \\
(0.19)\end{array}$ & $\begin{array}{l}13.449 \\
(1.84) *\end{array}$ & $\begin{array}{l}9.291 \\
(1.24)\end{array}$ \\
\hline EG5 & & & & & & $\begin{array}{l}4.63 \\
(0.76)\end{array}$ & $\begin{array}{l}3.681 \\
(0.66)\end{array}$ & $\begin{array}{l}13.502 \\
(1.87) *\end{array}$ & $\begin{array}{l}10.792 \\
(1.47)\end{array}$ \\
\hline EG6 & & & & & & $\begin{array}{l}-5.596 \\
(-0.87)\end{array}$ & $\begin{array}{l}-6.448 \\
(-1.09)\end{array}$ & $\begin{array}{l}-12.837 \\
(-1.66) *\end{array}$ & $\begin{array}{l}-13.194 \\
(-1.71) *\end{array}$ \\
\hline Trade1 & & & & $\begin{array}{l}-2.788 \\
(-1.55)\end{array}$ & $\begin{array}{l}-5.33 \\
(2.63) * *\end{array}$ & & & $\begin{array}{l}-2.972 \\
(-1.66) *\end{array}$ & $\begin{array}{l}-5.501 \\
(-2.71) * *\end{array}$ \\
\hline Trade2 & & & & $\begin{array}{l}-1.841 \\
(-1.01)\end{array}$ & $\begin{array}{l}-5.182 \\
(2.53) *\end{array}$ & & & $\begin{array}{l}-2.04 \\
(-1.12)\end{array}$ & $\begin{array}{l}-5.352 \\
(-2.61) * *\end{array}$ \\
\hline Trade3 & & & & $\begin{array}{l}-2.93 \\
(-1.55)\end{array}$ & $\begin{array}{l}-6.134 \\
(-2.91) * *\end{array}$ & & & $\begin{array}{l}-3.119 \\
(-1.66) *\end{array}$ & $\begin{array}{l}-6.276 \\
(-2.97) * * *\end{array}$ \\
\hline Trade4 & & & & $\begin{array}{l}-1.983 \\
(-1.36)\end{array}$ & $\begin{array}{l}-3.618 \\
(-2.37) *\end{array}$ & & & $\begin{array}{l}-2.175 \\
(-1.5)\end{array}$ & $\begin{array}{l}-3.737 \\
(-2.43) * *\end{array}$ \\
\hline Trade5 & & & & $\begin{array}{l}-1.531 \\
(-0.94)\end{array}$ & $\begin{array}{l}-3.013 \\
(-1.77) *\end{array}$ & & & $\begin{array}{l}-1.938 \\
(-1.17)\end{array}$ & $\begin{array}{l}-3.446 \\
(-1.99) * *\end{array}$ \\
\hline Trade6 & & & & $\begin{array}{l}-2.485 \\
(-1.63)\end{array}$ & $\begin{array}{l}-3.25 \\
(-2.05) * *\end{array}$ & & & $\begin{array}{l}-2.34 \\
(-1.53)\end{array}$ & $\begin{array}{l}-3.401 \\
(-2.14) * *\end{array}$ \\
\hline Trans 1 & & & & $\begin{array}{l}-0.53 \\
(-0.07)\end{array}$ & $\begin{array}{l}-10.257 \\
(-1.11)\end{array}$ & & & $\begin{array}{l}-0.109 \\
(-0.01)\end{array}$ & $\begin{array}{l}-12.294 \\
(-1.31)\end{array}$ \\
\hline Trans2 & & & & $\begin{array}{l}-6.98 \\
(-0.92)\end{array}$ & $\begin{array}{l}-20.689 \\
(-2.28) * *\end{array}$ & & & $\begin{array}{l}-7.49 \\
(-0.95)\end{array}$ & $\begin{array}{l}-22.469 \\
(-2.43) * *\end{array}$ \\
\hline Trans3 & & & & $\begin{array}{l}-2.04 \\
(-0.26)\end{array}$ & $\begin{array}{l}-16.874 \\
(-1.78) *\end{array}$ & & & $\begin{array}{l}-3.096 \\
(-0.38)\end{array}$ & $\begin{array}{l}-18.643 \\
(-1.95) *\end{array}$ \\
\hline Trans4 & & & & $\begin{array}{l}-16.042 \\
(-2.79) * * *\end{array}$ & $\begin{array}{l}-14.526 \\
(-2.32) * *\end{array}$ & & & $\begin{array}{l}-21.518 \\
(-3.24) * * *\end{array}$ & $\begin{array}{l}-20.194 \\
(-2.70) * *\end{array}$ \\
\hline Trans5 & & & & $\begin{array}{l}-16.543 \\
(-2.66) * * *\end{array}$ & $\begin{array}{l}-10.342 \\
(-1.43)\end{array}$ & & & $\begin{array}{l}-21.586 \\
(-2.98) * * *\end{array}$ & $\begin{array}{l}-16.09 \\
(-1.87) *\end{array}$ \\
\hline Trans6 & & & & $\begin{array}{l}-11.379 \\
(-2.02) * *\end{array}$ & $\begin{array}{l}-3.78 \\
(-0.62)\end{array}$ & & & $\begin{array}{l}-9.161 \\
(-1.45)\end{array}$ & $\begin{array}{l}-4.468 \\
(-0.64)\end{array}$ \\
\hline Info1 & & & & & $\begin{array}{l}56.079 \\
(1.94) *\end{array}$ & & & & $\begin{array}{l}42.819 \\
(1.43)\end{array}$ \\
\hline Info2 & & & & & $\begin{array}{l}77.363 \\
(2.69) * *\end{array}$ & & & & $\begin{array}{l}64.062 \\
(2.13) * *\end{array}$ \\
\hline Info3 & & & & & $\begin{array}{l}76.346 \\
(2.55) * *\end{array}$ & & & & $\begin{array}{l}62.273 \\
(1.98) *\end{array}$ \\
\hline Info4 & & & & & $\begin{array}{l}5.077 \\
(0.21)\end{array}$ & & & & $\begin{array}{l}-11.365 \\
(-0.42)\end{array}$ \\
\hline Info5 & & & & & $\begin{array}{l}-15.188 \\
(-0.57)\end{array}$ & & & & $\begin{array}{l}-30.176 \\
(-1.06)\end{array}$ \\
\hline Info6 & & & & & $\begin{array}{l}-31.309 \\
(-1.27)\end{array}$ & & & & $\begin{array}{l}-37.381 \\
(-1.4)\end{array}$ \\
\hline Constant & $\begin{array}{l}-6.945 \\
(-35.31) * *\end{array}$ & $\begin{array}{l}-7.131 \\
=(-34.99) * * \\
\end{array}$ & $\begin{array}{l}-6.868 \\
\leqslant(-31.91) * *\end{array}$ & $\begin{array}{l}-6.422 \\
(-12.57) * * \\
\end{array}$ & $\begin{array}{l}-6.151 \\
<(-9.29) * * * \\
\end{array}$ & $\begin{array}{l}-6.85 \\
k(-32.76) * * \\
\end{array}$ & $\begin{array}{l}-7.111 \\
(-36.17) * *\end{array}$ & $\begin{array}{c}-6.301 \\
*(-12.31) * * \\
\end{array}$ & $\begin{array}{l}-5.787 \\
(-8.21) * * *\end{array}$ \\
\hline Observatic & $\begin{array}{ll}c & 231\end{array}$ & 231 & 231 & 216 & 216 & 231 & 231 & 216 & 216 \\
\hline Number of & 26 & 26 & 26 & 24 & 24 & 26 & 26 & 24 & 24 \\
\hline R-squared & 0.84 & 0.85 & 0.82 & 0.87 & 0.88 & 0.84 & 0.86 & 0.87 & 0.88 \\
\hline
\end{tabular}

$\mathrm{t}$-statistics in parentheses

$*$ significant at $10 \%$ level, ** significant at $5 \%$ level; $* * *$ significant at $1 \%$ level 
Appendix Figure A1: Kernel Density and Normal Distribution (1990)

All regions (value added per worker)

Core (value adde per worker)
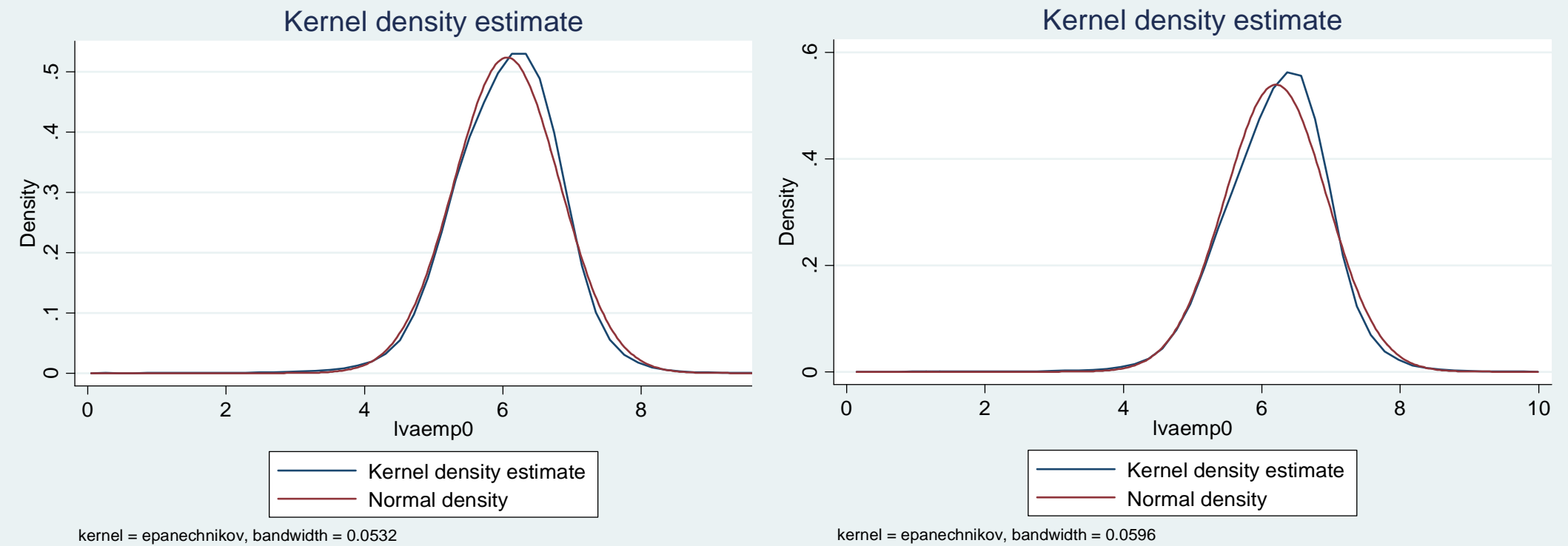

kernel $=$ epanechnikov, bandwidth $=0.059$

All regions (TFP)

Core (TFP)
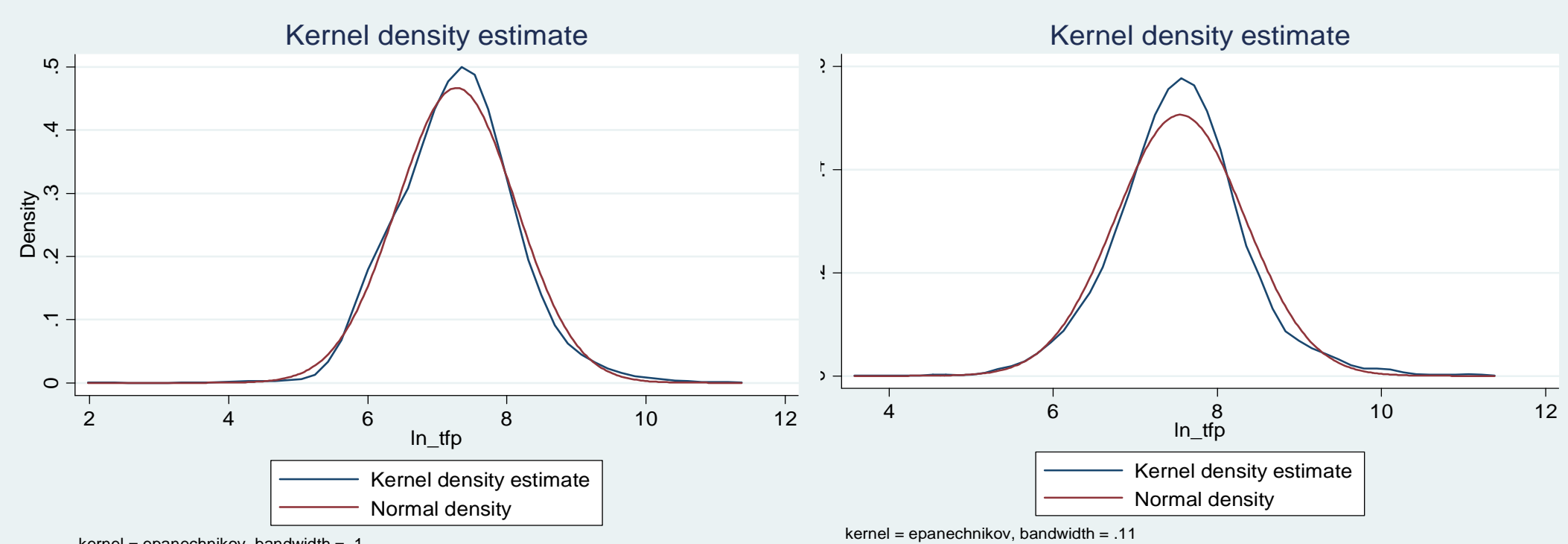

kernel $=$ epanechnikov, bandwidth $=.1$ 
Appendix Table A1: Regional Regression with Localization (TFP contributions)

\begin{tabular}{|c|c|c|}
\hline & 1 & \\
\hline $\mathrm{mu}$ & $\begin{array}{l}0.077 \\
(5.40) * * *\end{array}$ & $\begin{array}{l}0.078 \\
(5.46) * * *\end{array}$ \\
\hline sigma & $\begin{array}{l}0.033 \\
(1.95) *\end{array}$ & $\begin{array}{l}0.034 \\
(1.98) * *\end{array}$ \\
\hline MKT & $\begin{array}{l}0.115 \\
(0.44)\end{array}$ & \\
\hline localization1 & $\begin{array}{l}0.092 \\
(4.08) * * *\end{array}$ & $\begin{array}{l}0.092 \\
(4.09) * * *\end{array}$ \\
\hline localization2 & $\begin{array}{l}0.075 \\
(3.34) * * *\end{array}$ & $\begin{array}{l}0.076 \\
(3.40) * * *\end{array}$ \\
\hline localization3 & $\begin{array}{l}0.08 \\
(3.57) * * *\end{array}$ & $\begin{array}{l}0.08 \\
(3.58) * * *\end{array}$ \\
\hline localization4 & $\begin{array}{l}0.061 \\
(2.74) * * *\end{array}$ & $\begin{array}{l}0.061 \\
(2.73) * * *\end{array}$ \\
\hline localization5 & $\begin{array}{l}0.043 \\
(1.91) *\end{array}$ & $\begin{array}{l}0.043 \\
(1.91) *\end{array}$ \\
\hline ma1 & $\begin{array}{l}0.725 \\
(0.83)\end{array}$ & $\begin{array}{l}0.119 \\
(0.14)\end{array}$ \\
\hline ma2 & $\begin{array}{l}-0.855 \\
(-0.98)\end{array}$ & $\begin{array}{l}-1.447 \\
(-1.72) *\end{array}$ \\
\hline ma3 & $\begin{array}{l}0.552 \\
(0.65)\end{array}$ & \\
\hline ma4 & $\begin{array}{l}-0.036 \\
(-0.04)\end{array}$ & $\begin{array}{l}-0.565 \\
(-0.67)\end{array}$ \\
\hline ma5 & $\begin{array}{l}-0.016 \\
(-0.02)\end{array}$ & $\begin{array}{l}-0.509 \\
(-0.61)\end{array}$ \\
\hline ma6 & & $\begin{array}{l}-0.483 \\
(-0.58)\end{array}$ \\
\hline tech1 & $\begin{array}{l}0.194 \\
(0.61)\end{array}$ & $\begin{array}{l}0.058 \\
(0.91)\end{array}$ \\
\hline tech2 & $\begin{array}{l}0.165 \\
(0.66)\end{array}$ & $\begin{array}{l}0.06 \\
(0.93)\end{array}$ \\
\hline tech3 & $\begin{array}{l}0.133 \\
(0.70)\end{array}$ & $\begin{array}{l}0.055 \\
(0.85)\end{array}$ \\
\hline tech4 & $\begin{array}{l}0.119 \\
(0.82)\end{array}$ & $\begin{array}{l}0.062 \\
(0.96)\end{array}$ \\
\hline tech5 & $\begin{array}{l}0.058 \\
(0.66)\end{array}$ & $\begin{array}{l}0.032 \\
(0.50)\end{array}$ \\
\hline urbanization1 & $\begin{array}{l}-0.13 \\
(-0.59)\end{array}$ & $\begin{array}{l}-0.035 \\
(-0.16)\end{array}$ \\
\hline urbanization2 & $\begin{array}{l}0.037 \\
(0.17)\end{array}$ & $\begin{array}{l}0.132 \\
(-0.61)\end{array}$ \\
\hline urbanization3 & $\begin{array}{l}-0.099 \\
(-0.45)\end{array}$ & \\
\hline urbanization4 & & $\begin{array}{l}0.105 \\
(0.48)\end{array}$ \\
\hline urbanization5 & $\begin{array}{l}0.227 \\
(1.04)\end{array}$ & $\begin{array}{l}0.326 \\
(1.50)\end{array}$ \\
\hline urbanization6 & $\begin{array}{l}0.431 \\
(1.98) *\end{array}$ & $\begin{array}{l}0.529 \\
(2.44) * *\end{array}$ \\
\hline Constant & $\begin{array}{l}-1.587 \\
(-0.42) \\
\end{array}$ & $\begin{array}{l}0.056 \\
(0.52) \\
\end{array}$ \\
\hline Observations & 282 & 282 \\
\hline Number of pre & 47 & 47 \\
\hline R-squared & 0.26 & 0.26 \\
\hline
\end{tabular}

t-statistics in parentheses

** significant at $5 \%$ level; $* * *$ significant at $1 \%$ level 
Appendix Table A2: Sectoral Regressions with localization Index

\begin{tabular}{|c|c|c|c|c|c|}
\hline & 1 & 2 & 3 & $\begin{array}{l}34 \\
\end{array}$ & \\
\hline $\mathrm{mu}$ & $\begin{array}{l}0.896 \\
(8.27) * * *\end{array}$ & $\begin{array}{l}0.686 \\
(6.03) * * *\end{array}$ & $\begin{array}{l}0.777 \\
(6.38) * * *\end{array}$ & $\begin{array}{l}0.798 \\
(6.61) * * *\end{array}$ & \\
\hline sigma & $\begin{array}{l}3.05 \\
(19.51) * * *\end{array}$ & $\begin{array}{l}3.271 \\
(19.45) * * *\end{array}$ & $\begin{array}{l}3.275 \\
(18.80) * * *\end{array}$ & $\begin{array}{l}3.336 \\
*(19.11) * * *\end{array}$ & \\
\hline core & $\begin{array}{l}0.681 \\
(6.37) * * *\end{array}$ & & $\begin{array}{l}0.643 \\
(6.02) * * *\end{array}$ & $\begin{array}{l}0.649 \\
(6.14) * * *\end{array}$ & \\
\hline Loc1 & $\begin{array}{l}1.758 \\
(4.68) * * *\end{array}$ & $\begin{array}{l}1.901 \\
(4.59) * * *\end{array}$ & $\begin{array}{l}1.511 \\
(2.46) * * *\end{array}$ & $\begin{array}{l}0.389 \\
(0.43)\end{array}$ & $\begin{array}{l}\text { Note: Loc } 1 \text { to Loc } 6 \text { are the localization index derived } \\
\text { from Nakajima et al. (2011) }\end{array}$ \\
\hline Loc2 & $\begin{array}{l}1.705 \\
(4.57) * * *\end{array}$ & $\begin{array}{l}1.8 \\
(4.38) * * *\end{array}$ & $\begin{array}{l}1.971 \\
(3.21) * * *\end{array}$ & $\begin{array}{l}0.597 \\
(0.67)\end{array}$ & \\
\hline Loc3 & $\begin{array}{l}1.691 \\
(4.51) * * *\end{array}$ & $\begin{array}{l}1.741 \\
(4.22) * * *\end{array}$ & $\begin{array}{l}1.975 \\
(3.12) * * *\end{array}$ & $\begin{array}{l}0.683 \\
(0.76)\end{array}$ & \\
\hline Loc4 & $\begin{array}{l}0.486 \\
(1.47)\end{array}$ & $\begin{array}{l}0.552 \\
(1.51)\end{array}$ & $\begin{array}{l}1.276 \\
(2.09) * * *\end{array}$ & $\begin{array}{l}2.339 \\
(2.32) * *\end{array}$ & \\
\hline Loc5 & $\begin{array}{l}0.533 \\
(1.59)\end{array}$ & $\begin{array}{l}0.651 \\
(1.77) *\end{array}$ & $\begin{array}{l}0.976 \\
(1.57)\end{array}$ & $\begin{array}{l}2.506 \\
(2.75) * * *\end{array}$ & \\
\hline Loc6 & $\begin{array}{l}0.392 \\
(1.20)\end{array}$ & $\begin{array}{l}0.522 \\
(1.46)\end{array}$ & $\begin{array}{l}0.458 \\
(0.76)\end{array}$ & $\begin{array}{l}1.986 \\
(2.19) * *\end{array}$ & \\
\hline Trade1 & & & $\begin{array}{l}-3.341 \\
(-1.59)\end{array}$ & $\begin{array}{l}-2.48 \\
(-1.1)\end{array}$ & \\
\hline Trade2 & & & $\begin{array}{l}-3.33 \\
(-1.56)\end{array}$ & $\begin{array}{l}-2.428 \\
(-1.06)\end{array}$ & \\
\hline Trade3 & & & $\begin{array}{l}-4.335 \\
(1.98) *\end{array}$ & $\begin{array}{l}-3.457 \\
(-1.47)\end{array}$ & \\
\hline Trade4 & & & $\begin{array}{l}-0.844 \\
(-0.57)\end{array}$ & $\begin{array}{l}-1.923 \\
(-1.11)\end{array}$ & \\
\hline Trade5 & & & $\begin{array}{l}0.18 \\
(0.10)\end{array}$ & $\begin{array}{l}-1.436 \\
(-0.68)\end{array}$ & \\
\hline Trade6 & & & $\begin{array}{l}0.033 \\
(0.02)\end{array}$ & $\begin{array}{l}-1.486 \\
(-0.78)\end{array}$ & \\
\hline Trans1 & & & $\begin{array}{l}16.755 \\
(1.62)\end{array}$ & $\begin{array}{l}8.251 \\
(0.68)\end{array}$ & \\
\hline Trans2 & & & $\begin{array}{l}7.468 \\
(0.73)\end{array}$ & $\begin{array}{l}-2.25 \\
(-0.19)\end{array}$ & \\
\hline Trans3 & & & $\begin{array}{l}11.189 \\
(1.07)\end{array}$ & $\begin{array}{l}2.344 \\
(-0.19)\end{array}$ & \\
\hline Trans4 & & & $\begin{array}{l}-5.053 \\
(-0.75)\end{array}$ & $\begin{array}{l}-8.961 \\
(-1.24)\end{array}$ & \\
\hline Trans5 & & & $\begin{array}{l}-3.478 \\
(-0.45)\end{array}$ & $\begin{array}{l}-5.676 \\
(-0.7)\end{array}$ & \\
\hline Trans6 & & & $\begin{array}{l}3.693 \\
(0.55)\end{array}$ & $\begin{array}{l}1.039 \\
(0.15)\end{array}$ & \\
\hline Info1 & & & & $\begin{array}{l}15.412 \\
(0.38)\end{array}$ & \\
\hline Info2 & & & & $\begin{array}{l}29.385 \\
(0.73)\end{array}$ & \\
\hline Info3 & & & & $\begin{array}{l}23.666 \\
(0.58)\end{array}$ & \\
\hline Info4 & & & & $\begin{array}{l}-67.653 \\
(-1.66) *\end{array}$ & \\
\hline Info5 & & & & $\begin{array}{l}-88.05 \\
(-2.26) * *\end{array}$ & \\
\hline Info6 & & & & $\begin{array}{l}-86.522 \\
(-2.31) * *\end{array}$ & \\
\hline Constant & $\begin{array}{l}-7.583 \\
(-31.35) * *\end{array}$ & $\begin{array}{l}-7.343 \\
k(-27.88) * *\end{array}$ & $\begin{array}{l}-7.798 \\
k(-10.61) * *\end{array}$ & $\begin{array}{l}-7.236 \\
*(-9.22) * * *\end{array}$ & \\
\hline Observatic & c $\quad 216$ & 216 & 216 & 216 & \\
\hline Number of & 24 & 24 & 24 & 24 & \\
\hline R-squared & 0.87 & 0.84 & 0.88 & 0.89 & \\
\hline
\end{tabular}

